\title{
Summary
}

Oleksii Shyian. Some issues of state regulation of the National innovation system of Ukraine.

In the Article it has been outlined the problems of absence of definition of the national innovation system of Ukraine in the Ukrainian Laws. In addition, it has been paid attention that there is no unique position about definition of national innovation system in scientific field.

In order to improve the development of the innovation sphere in Ukraine, it is necessary to regulate the issues of the national innovation system, its elements (subsystems), the principles of interaction of elements (subsystems) among it etc. at the legislative level in the Law of Ukraine "On Innovative Activity".

The development of the innovation sphere requires comprehensive state regulation on all elements of the national innovation system. There is a problem nowadays - so-called separation of science from practice, the lack of practical use and (or) commercialization of scientific inventions and developments. Scientific developments and inventions are unnecessary for the current application and practice of production, management. These inventions and developments are often left in the laboratory or at research institutes and never brought to life.

From our point of view, the problem of separation of science from practice is caused by the level of insufficient functional connections of subsystems of the national innovation system of Ukraine. In this situation, each subsystem is partly isolated from the other subsystems and evolves independently.

On the basis of the considered material, it has been proposed an author's definition of the national innovation system as a coherent system of innovation actors who carry out, provide and / or facilitate the development, commercialization and practical application of intellectual output to create (apply) innovation.

The author proposed to amend the Law of Ukraine "On Innovative Activity", in particular to consolidate the definition of the national innovation system in this Law.

Key words: state regulation, innovative activity, national innovation system, innovation.

DOI: $10.36695 / 2219-5521.1 .2020 .33$

УдК 342.9:58(1-751.3)(477)

\section{т.П. РОДІК}

Тетяна Петрівна Родік, аспірант Академії праці, соціальних відносин і туризму Федерації профресійних спілок України*

ORCID: 0000-0003-3681-368X

\section{УДОСКОНАЛЕННЯ АДМІНІСТРАТИВНО-ПРАВОВОЇ ОХОРОНИ ДЕНДРОЛОГІЧНИХ ПАРКІВ В УКРАЇНІ}

Постановка проблеми. Дендрологічні парки в нашій державі є важливими осередками збереження біологічного різноманіття, мають значну історико-культурну та природоохоронну цінність, а деякі дендрологічні парки, маючи заповідний статус, є ключовими територіями у формуванні екомережі. Ефективність функціонування дендропарків як природоохоронних, рекреаційних, культурно-освітніх, науково-дослідних установ можливе лише за умови ефективної правової охорони. 3 огляду на це актуальними є дослідження особливостей адміністративно-правової охорони дендрологічних парків, виявлення недоліків у правовому регулюванні вказаного питання, а також пошуку шляхів удосконалення правової регламентації охорони дендропарків.

Аналіз останніх досліджень і публікацій. Окремим теоретичним та практичним питанням правової охорони навколишнього природного середовища, природно-заповідного фонду України та його складових категорій присвячені праці О.А. Улютіної, І.Д. Казанчук, Л.П. Коваленко, В.С. Сршової, Я. Герасименко, Р.А. Гольонко та ін.

Формулювання мети статті. Основною метою даної статті є окреслення особливостей та проблем, які перешкоджають належному здійсненню адміністративно-правової охорони й визначення шляхів вдосконалення адміністративно-правової охорони дендрологічних парків.

Виклад основного матеріалу. Ефективна правова охорона дендрологічних парків має важливе значення, оскільки йдеться про охорону унікальних об'єктів культурної спадщини, парків-пам'яток садово-паркового мистецтва, пам'яток природи, що мають заповідний статус, та про збереження генетичного фонду живої природи загалом.

Досліджуючи правову охорону дендропарків, необхідно зробити акцент саме на адміністративно-правовій охороні. У цьому ми цілком погоджуємось 3 думкою В.С. Єршової про те, що в рамках адміністративноправової охорони передбачена найбільша частина заходів, які спрямовані на використання всієї сукупності адміністративно-правових засобів, способів, методів впливу на суспільні відносини у цій сфері (йдеться про охорону навколишнього природного середовища в цілому), спрямованих на недопущення порушень допустимих меж поведінки людей, а також забезпечення правопорядку та належного управління з боку держави 1 .

(C) Т.П. Родік, 2020

* Tetiana Rodik, Postgraduate student Academy of Labor, Social relations and Tourism Federation of Trade Unions of Ukraine 
Адміністративно-правова охорона спрямована на забезпечення дотримання правового режиму дендропарків, ефективне управління ними, на недопущення порушень установлених правових норм, якими визначено засади функціонування парків.

Відповідно до ст. 5 Закону України «Про охорону навколишнього природного середовища» від 25 червня 1991 р. дендрологічні парки в нашій державі охороняються як національне надбання, щодо якого встановлюється особливий режим охорони, відтворення й використання. Даним законодавчим актом, а саме ст. 60, також визначено органи і громадські організації, які забезпечують охорону дендропарків і регулюють їх використання на території України².

Законом України «Про природно-заповідний фонд України» визначено правові основи щодо організації, діяльності, охорони, використання і відтворення дендрологічних парків та управління ними. Деякі вітчизняні науковці Закон України «Про природно-заповідний фонд України» характеризують як один із найбільш детально регламентованих актів відповідного спрямування 3 точки зору формальної визначеності, правового режиму окремих категорій територій та об'єктів, що охороняються, закладених наукових засад «консервативної» охорони (тобто охорони шляхом збереження) ${ }^{3}$.

Зокрема, ст. 6 вищезазначеного Закону закріплено положення, відповідно до якого території та об’єкти, що мають особливу екологічну, наукову, естетичну, господарську, а також історико-культурну цінність, підлягають комплексній охороні, порядок здійснення якої визначається положенням щодо кожної 3 таких територій чи об'єктів. Також питання охорони дендрологічних парків як складової природно-заповідного фонду в загальному вигляді врегульовані в Розділі IX вказаного Закону, який містить положення про склад та повноваження служби охорони територій та об'єктів природно-заповідного фонду, здійснення державного й громадського контролю за додержанням режиму територій та об'єктів природно-заповідного фонду4.

Переходячи до з'ясування особливостей адміністративно-правової охорони дендропарків, слід звернути увагу на те, що національне законодавство не закріплює ані визначення «адміністративно-правова охорона дендрологічних парків» ані визначення більш ширшого поняття «правова охорона дендрологічних парків». Не закріплено також принципи, зміст та особливості правової охорони дендрологічних парків як унікальних науково-дослідних установ та цінних природних територій, що, на нашу думку, є вагомою прогалиною в правовому регулюванні порядку функціонування останніх.

Слушною буде думка Р.А. Гольонко про те, що незважаючи на існування окремих законодавчих положень про організацію охорони територій та об'єктів природно-заповідного фонду, слід констатувати, що на сьогодні національне законодавство не містить юридичного визначення поняття «правова охорона природно-заповідного фонду України» 5 .

Ефективність адміністративно-правової охорони дендропарків безпосередньо залежить від уніфікації понятійного й термінологічного апарату чинного законодавства України.

Низка концептуальних, понятійних, термінологічних і організаційних, невідповідностей пронизує увесь комплекс законодавчих актів України, які так чи інакше дотичні до правового забезпечення функціонування територій та об’єктів природно-заповідного фонду.

Дендрологічним паркам в нашій державі притаманна поліфункціональність, яка реалізується в природоохоронній, рекреаційній, культурно-освітній, науково-дослідній функціях.

Поліфункціональні парки є перспективними для розширення заповідної мережі, бо вони - не лише історичне і культурне надбання, а й невід’ємний елемент виховання молоді, об'єкт наукових досліджень, джерело збагачення регіональних рослинних ресурсів ${ }^{6}$. I саме багатофункціональність парку вимагає комплексного підходу щодо визначення правових основ його діяльності та охорони.

Саме щодо цього і різняться твердження та висновки вчених. Зокрема, на думку Н.Д. Красіліч, дендрологічні парки як природні об'єкти, що мають штучне походження, не наділені заповідним режимом і порівняно із заповідними об'єктами мають інші цілі й завдання, а тому їх слід відносити до категорії природнокультурних об'єктів і комплексів 7 .

В.М. Бевзенко пропонує виключити штучно створені об'єкти і комплекси зі складу природно-заповідного фонду ${ }^{8}$.

Проте О.М. Ковтун з такою точкою зору не погоджується і зазначає, що основними цінностями об'єктів культурної спадщини є антропологічна, археологічна, естетична, етнографічна, історична, мистецька, наукова чи художня, а територій та об'єктів природно-заповідного фонду - природоохоронна, наукова, естетична і рекреаційна (саме ці цілі є пріоритетними і для штучно створених територій та об'єктів природно-заповідного фонду $)^{9}$.

Як зазначалось вище, дендрологічні парки підлягають комплексній охороні, порядок здійснення якої визначається положеннями, затверджуваними центральним органом виконавчої влади в галузі охорони навколишнього природного середовища та центральним органом виконавчої влади в галузі культури. Проте чинним законодавством не встановлено чіткого механізму щодо створення та функціонування об'єктів, які поєднують у собі культурні йі природоохоронні функції.

Зокрема колізії стосуються базових у даній сфері законів, таких як Закон України «Про природно-заповідний фонд України», Закон України «Про екологічну мережу України», та Закон України «Про охорону навколишнього природного середовища». У такій ситуації для практичного застосування норми закону має бути підкріплення підзаконними актами, а це призводить, практично, до відсутності узгодження в системі природоохоронного законодавства. Наприклад, і досі існує колізія щодо категорій територій та об'єктів природно-заповідного фонду, визначених Законом України «Про природно-заповідний фонд України» і Законом України «Про охорону навколишнього природного середовища» та інших типів природоохоронних територій, які передбачені Водним, Земельним та Лісовим кодексами України. 
Не можна не погодитись із М.О. Подольховою, яка відмітила, що законодавча база щодо функціонування дендрологічних парків грунтовно розроблена, проте має і деякі суперечності. Так, Законом України «Про природно-заповідний фонд України» передбачено надання пільг відповідним органам, які забезпечують функціонування дендрологічних парків (розділ VI, ст. ст. 44, 49). Проте з 2015 р. скасовано пільги на звільнення від сплати земельного податку ${ }^{10}$, що спричинило низку проблем для дендрологічних парків і ботанічних садів. Це питання наразі передано місцевим органам влади, які вирішують його на власний розсуд. Як наслідок, не всі природоохоронні установи отримали вказану пільгу. Урегулювання цього питання залишається надзвичайно важливим, оскільки в ряді випадків розмір податку становить маиже половину обсягу бюджетного фінансування установи, а іноді навіть перевищує иого ${ }^{11,12}$.

Відповідно до ст. 3 Закону України «Про природно-заповідний фонд України» дендрологічні парки, залежно від їх екологічної і наукової, історико-культурної цінності, можуть бути загальнодержавного або місцевого значення ${ }^{13}$. При наданні відповідного адміністративного рангу дендрологічним паркам, як штучно створеним об'єктам природно-заповідного фонду, мають бути застосовані певні критерії. Однак дані критеpiї та методики їх визначення недостатньо чіткі та мають рекомендаційний характер.

Ефективність адміністративно-правової охорони дендропарків безпосередньо залежить від законодавчо закріпленого їх правового режиму. Стосовно дендрологічних парків законодавчо встановлюється змішаний заповідний режим, в основу якого закладено принцип функціонального зонування, який передбачає можливість існування в межах одного природного комплексу окремих ділянок з регульовано-заповідним режимом, а також території з обмеженим господарським використанням.

Як уже зазначалось вище, Законом України «Про природно-заповідний фонд України» щодо дендрологічних парків встановлено особливий режим охорони, відтворення й використання, проте при встановлені даного режиму не враховано особливості щодо поліфункціональності парку.

Істотним недоліком законодавства $\epsilon$ те, що недостатньо визначеним $є$ правовий режим поліфункціональних зон дендрологічних парків (крім заповідної зони), не міститься чіткого, вичерпного переліку видів дозволеної та забороненої діяльності на їхній території.

Таким чином, зазначені вище проблеми значною мірою зумовлені або відсутністю в українському законодавстві відповідних нормативних положень і визначень, неузгодженістю різних законодавчих та підзаконних актів щодо трактування понять і категорій, визначення ключових положень та вимог до практичного втілення тих чи інших заходів, або покладанням на відповідні органи управління одночасно господарських i природоохоронних функцій, що створює конфлікт інтересів.

Сформована система органів державного управління в нашій державі $є$ неефективною. Існуюча так звана відомча розпорошеність дендрологічних парків, низка колізій у правових положеннях та поєднання у суб'єктів реалізації державної політики у сфері природно-заповідної справи функцій контролю, управління, 3 господарською діяльністю не дають змоги сформувати чіткий вектор управлінської діяльності для даної категорії природно-заповідного фонду. Дендрологічні парки України як загальнодержавного, так і місцевого значення знаходяться у підпорядкуванні держлісгоспів, науково-дослідних установ, університетів, лісництв, міських та сільських рад, а також у приватній власності.

На сьогодні, враховуючи розгалуженість суб'єктів управління природно-заповідним фондом України, важливим та необхідним є забезпечення цілісності управління природно-заповідним фондом України 3 урахуванням як загальних засад цієї діяльності, так і особливостей ії організації різними суб'єктами.

3 кожним роком державна політика України в сфері розвитку заповідної справи та інших особливо охоронюваних територій удосконалюється, проте, на жаль, правова база не повною мірою забезпечує потреби правозастосування. Сьогодні досить актуальним є питання щодо удосконалення національного законодавства і приведення у відповідність до законодавства Свропейського Союзу з урахуванням відповідних міжнародних зобов’язань України у сфері сталого розвитку та подальшого розвитку заповідної справи. Дійсно, сьогодні в Україні є певний досвід правової охорони дендрологічних парків, проте існує гостра необхідність розширення нормативно-правового забезпечення діяльності даних об'єктів у зв'язку з виникненням низки якісно нових, соціально-економічних, суспільно культурних та інших умов.

Висновки. Отже, на нашу думку, необхідно централізувати існуючу систему управління та враховуючи поліфункціональність дендропарків і відомчу розпорошеність, підпорядкувати дендрологічні парки єдиному органу. Важливим моментом при вирішенні даного питання має бути наукова діяльність парків. Оскільки саме фундаментальні та прикладні дослідження науковців нададуть дендропаркам розвиток на далеку перспективу.

I, звичайно ж, реалізація шляхів удосконалення адміністративно-правової охорони дендропарків безпосередньо залежить від уніфікації понятійного й термінологічного апарату чинного законодавства України, усунення колізій правових норм, удосконалення національного законодавства і приведення у відповідність до законодавства Європейського Союзу.

1 Єршова В.С. До розуміння сутності адміністративно-правової охорони навколишнього природного середовища в Україні. Науковий вісник Херсонського державного університету. 2014. Вип. 1. Т. 2. С. 118-124 (Серія «Юридичні науки»).

2 Про охорону навколишнього природного середовища: Закон України від 25 червня 1991 р. № 1264-XII. URL: https://zakon. rada.gov.ua/laws/show/1264-12\#n290 (дата звернення: 01.03.2020).

3 Гродзинський М.Д., Стеценко М.П. Заповідна справа в Україні : навч. посіб. Київ, 2003. 306 с.

4 Про природно-заповідний фонд України: Закон України від 16 червня 1992 р. № 2456 - XII. URL: http://zakon.rada.gov. ua/laws/show/2456-12 (дата звернення: 01.03.2020).

5 Гольонко Р.А. Поняття та особливості правової охорони біосферних заповідників в Україні. Проблеми законності. 2017. Вип. 139. С. 176-191. 
6 Решетюк О.В. Перспективи використання парків природно-заповідного фонду Буковини для збагачення ії біорізноманіття. Науковий вісник НЛТУ Украӥни. 2017. Вип. 27(10). С. 42-50.

7 Красилич Н.Д. Организационно-правовые вопросы охраны природно-заповедного фонда: дис. ... канд. юрид. наук: 12.00.06. Киев, 1988. 180 с.

8 Бевзенко В.М. Управління природно-заповідним фондом в Україні: організаційно-правові питання: дис. ... канд. юрид. наук: 12.00 .07 / Національний університет внутрішніх справ. Харків, 2005. 210 с.

9 Ковтун О.М. Правові аспекти охорони територій та об'єктів природно-заповідного фонду України: дис. ... канд. юрид. наук : 12.00.06 / Національний педагогічний університет імені М.П. Драгоманова. Київ, 2008. 233 с.

10 Податковий кодекс України: Закон України від 2 грудня 2010 р. № 2755-VI / Верховна Рада України. URL: http://zakon. rada.gov.ua/laws/show/2755-17 (дата звернення: 01.03.2020).

11 Про сучасний стан, проблеми і перспективи збереження та збагачення рослинного різноманіття в ботанічних садах та дендропарків України: постанова Президії Національної академії наук України від 01 липня 2015 p. № 170. URL: http://www. nas.gov.ua/legaltexts/DocPublic/P-150701-170-0.pdf

12 Подольхова М.О. Дендрологічні парки Українського Полісся (комплексна оцінка, територіальна організація та ландшафтно-композиційний аналіз). дис. ... канд. сільськогосподарських наук: 06.03.01 / Національний університет біоресурсів і природокористування України. Київ, 2018. 241 с.

13 Про природно-заповідний фонд України: Закон України від 16 червня 1992 p. № 2456-XII. URL: http://zakon.rada.gov. ua/laws/show/2456-12 (дата звернення: 01.03.2020).

\section{Резюме}

Родік Т.П. Удосконалення адміністративно-правової охорони дендрологічних парків в Україні.

У статті окреслено проблеми, які перешкоджають належному здійсненню адміністративно-правової охорони дендрологічних парків в Україні. Зокрема, зроблено аналіз окремих колізій в національному законодавстві та суперечностей в теоретичних наукових положеннях щодо правового забезпечення охорони дендропарків в нашій державі, роблячи акцент на адміністративно-правовій охороні.

Ключові слова: дендрологічний парк, правова охорона, адміністративно-правова охорона, охорона навколишнього природного середовища, охорона територій та об'єктів природно-заповідного фонду.

\section{Резюме}

Родик Т.П. Совершенствование администраивно-правовой охраны дендрологическиих парков в Украине.

В статье обозначены проблемы, которые препятствуют осуществлять административно-правовую охрану дендрологических парков в Украине надлежащим образом. В частности, сделан анализ отдельных коллизий в национальном законодательстве и противоречий в теоретических научных положениях относительно правового обеспечения охраны дендропарков в нашем государстве с акцентом на административно-правовую охрану.

Ключевые слова: дендрологический парк, правовая охрана, административно-правовая охрана, охрана окружающей природной среды, охрана территорий и объектов природно-заповедного фонда.

\section{Summary}

Tetiana Rodik. Improving administrative-legal protection of dendrological parks in Ukraine.

The article is devoted to the analysis of administrative-legal protection of dendrological parks and its peculiarities as well as identifications of drawbacks in this sort of legal regulations. We also target at the ways to improve legal reglamentation of dendrological parks' protection.

Only effective legal protection enables adequate functioning of dendrological parks as nature conservational, recreational, cultural, educational, and research institutions.

On having analysed the peculiarities of the administrative-legal protection of dendrological parks we draw attention to the fact that national legislation does operate neither the definitions for the term «administrative-legal protection of dendrological parks» nor for a more generic one «legal protection of dendrological parks». There are no principles, ideas or peculiarities for the legal protection of dendrological parksas unique research institutions and valuable natural areas. We consider this fact a drawback in the legal regulation of such territories functioning.

We have analyzed national legislation and juridical literature to define the meaning of the categories «legal protection of dendrological parks» and «administrative - legal protection of dendrological parks» to determine the ways to improve legal administrative protection of dendrological parks.

This article presents the research into the legislative base of dendrological parks functioning, which proved to be thoroughly developed although having some controversies. The system of state administration is ineffective in our country.

There is a range of issues, which do not permit to develop a clear administrative vector for such a category of the nature reserve fund. We can single out institutional dispersion among dendrological parks, some collisions in legislative acts. Moreover, bodies of state policy on nature reserve fund combine several functions: monitoring, managing, and economic activity.

The conclusions include the problems, which prevent the adequate realization of the administrative-legal protection of dendrological parks. We also develop ways to improve legal administrative protection of dendrological parks.

Key words: dendrological park, legal protection, administrative legal protection, regulatory support, protection of the environment, protection of territories and objects of the nature reserve fund. 